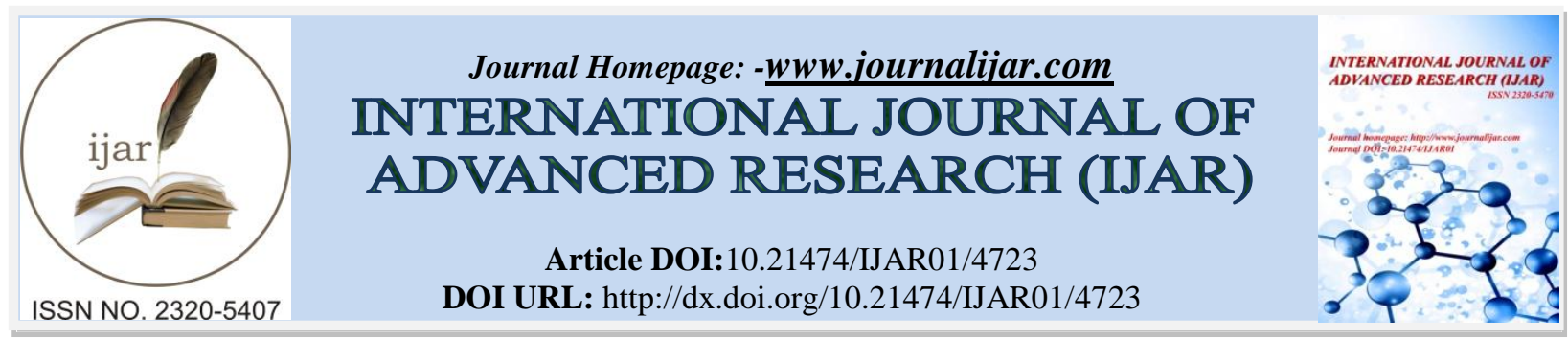

RESEARCH ARTICLE

\title{
CHARACTERIZATION AND INFLUENCE OF RAINY SEASON ONGROUND WATER QUALITY OF MORADABAD CITY.
}

\begin{abstract}
Anam Sayeed, Sameer Chandra ${ }^{2}$ and ${ }^{*}$ Jaspal Singh ${ }^{1}$.
1. Department of Environmental Science, Bareilly Collage, Bareilly, (U.P.) 243005.

2. Department of Plant Science, M.J.P. Rohilkhand University, Bareilly, (U.P.), 243006.
\end{abstract}

\section{Manuscript Info}

Manuscript History

Received: 4 May 2017

Final Accepted: 6 June 2017

Published: July 2017

\begin{abstract}
The purpose of given study was to analyze ground water quality of Moradabad industrial city. In a progressive country like India,withthe economic development as it one of the important aim. This leads to increase in industrial discharge and a wide range of pollutants reaching to water bodies. Water sample were collected from Moradabad city from five different sites viz. studied for Alkalinity, Hardness, Total suspended solid (TSS), Total dissolve Solid (TDS), Iron, Calcium, Chloride, Electrical conductivity (EC) and Dissolve oxygen (DO) during the pre and post rainy season. All Parameters were found within the permissible limits given by WHO (1984) and IS (1993). The study revealed that studied ground water of Moradabad industrial area is suitable for drinking purpose.
\end{abstract}

Copy Right, IJAR, 2017,. All rights reserved.

\section{Introduction:-}

The growing imbalance between supply and demand has resulted in pollution and environmental degradation. Fresh water is finite resource, essential for agriculture, industry and even human existence. Increase in urbanization, industrialization, agriculture activity and various human activities have enhanced the water pollution. The adequate quantity and quality of water necessary for sustainable development, World Health Origination (WHO) reports that approximately $50 \%$ of urban and $65 \%$ of rural India is facing the problem of fresh water supply. Groundwater is important source of drinking water therefore it is very essential to maintain its quality (Navneet Kumar, 2010). Intake of contaminated water is the source of several diseases. Analysis of ground water quality provided an idea about the degree of contamination level due the over exploitation and unwanted human interference (Tewariet al., 2010). Industrial effluents, Sewage, drainage, livestock production and fertilizers are the sources which bring changes in the physicochemical characteristics of ground water (Chandra et al., 2012), which have been subject to investigation, as a consequence of such deteriorate in water quality, water borne diseases such as diarrhea, dysentery, cholera and gastroenteritis occur. According to the world health organization (WHO), it has become necessary to monitor water quality to observe the demand and pollution level of ground water. Ground water quality has great worry not only to the scientist and researcher working on the related aspect in India but worldwide (Rizavi et al., 2013). Most of the population of Moradabad city depends on the ground water for drinking purpose (Jain and Agarwal, 2012). Given study is contributing basic knowledge about the effect of rainy season in the studied area. Moradabad is situated at the bank of River Ram Ganga (a tributary to the great Ganges). This city is situated in western U.P., province between $28^{\circ}-21^{\prime}$ to $28^{\circ}-16^{\prime}$ Latitude North and $78^{\circ}-4^{\prime}$ to 79 Longitude East. It is situated within the great Gangetic plain. South-west monsoon season brings rainfall is about $80 \%$ approximately, rainfall 
takes place from June to September. Throughout monsoon excess water is available for deep percolation to ground water

\section{Material and Method:-}

Five sites viz. Civil lines, Bangla Gawn, Petal Nagari, Harthala and Kurala selected for the present study. The water samples were collected in two season i.e. pre and post rainy in pre-cleaned plastic bottles, collected samples were immediately brought to the laboratory and analyses for various parameters. The standard methods of APHA (1995) were followed for the analysis.

\section{Result and Discussion:-}

pH: In the observed samples collected from the different site of Moradabad city for the characterization of water quality in pre rainy season $\mathrm{pH}$ level was found maximum $(6.39 \pm 0.26)$ at the station Kurla, minimum range $(6.12 \pm 0.12)$ was found at C.lines whereas the average was estimated 6.36 for the city. In the post rainy season it ranged from 7.54-7.22 the highest range was found at Kurla and the lowest at Harthal and the average was 7.37, while the recommended level of $\mathrm{pH}$ given by WHO (1984) is (6.5-9.2). It's revealed that pH of ground water of Moradabad city is suitable for house purpose

Dissolve Oxygen (DO): Dissolve oxygen is one of the key factor of natural or waste water it is influenced by the physio-chemical parameter and biological activity in the water body (Matti, 2001) in pre rainy season the maximum DO was noted $22.5 \mathrm{mgL}^{-1}$ at site B. Gawn area and minimum was noted at the Civil line $11.8 \mathrm{mgL}^{-1}$ and the overall average of the DO was noted $17.68 \mathrm{mgL}^{-1}$ in the city of the selected sites on the other hand DO in post rainy season was ranged from $23.5-12.8 \mathrm{mgL}^{-1}$ and the average was $18.68 \mathrm{mgL}^{-1}$ within the city among the studied sites.

Table 1:-Ground water characteristics of Moradabad city during pre-rainy season 2016

\begin{tabular}{|c|c|c|c|c|c|}
\hline Parameter & Civil line & Bangla Gawn & PeetalNagri & Harthala & Kurula \\
\hline pH & $6.12 \pm 0.12$ & $6.30 \pm 0.15$ & $6.22 \pm 0.63 *$ & $6.13 \pm 0.18$ & $6.39 \pm 0.26$ \\
\hline DO & $11.8 \pm 0.34$ & $22.3 \pm .1 .1 *$ & $17.1 \pm 0.51$ & 18.90 .74 & $19.2 \pm 0.48$ \\
\hline Hardness $\left(\mathrm{mgL}^{-1}\right)$ & $250 \pm 7.5$ & $206 \pm 6.18$ & $272 \pm 8.98$ & $355 \pm 10.6^{*}$ & $23.0 \pm 6.9$ \\
\hline Calcium $\left(\mathrm{mgL}^{-1}\right)$ & $55.9 \pm 1.11$ & $72.75 \pm 2.1$ & $70.75 \pm 2.88$ & $84.73 \pm 1.65^{*}$ & $64.55 \pm 1.6$ \\
\hline $\operatorname{TSS}\left(\mathrm{mgL}^{-1}\right)$ & $62 \pm 1.9$ & $78 \pm 1.56$ & $83 \pm 2.9^{*}$ & $74 \pm 2.96$ & $87 \pm 3.48$ \\
\hline TDS $\left(\mathrm{mgL}^{-1}\right)$ & $180.9 \pm 5.4$ & $92.2 \pm 2.4$ & $117 . .3 \pm 3.51$ & $164.2 \pm 9.8$ & $155.8 \pm 6.2^{*}$ \\
\hline EC & $73.5 \pm 2.94 *$ & $86.4 \pm 2.16$ & $78.3 \pm 2.73$ & $88.2 \pm 2.2$ & $85.0 \pm 2.9$ \\
\hline Chloride $\left(\mathrm{mgL}^{-1}\right)$ & $56.73 \pm 1.6^{*}$ & $75.16 \pm 2.25$ & $86.16 \pm 2.75$ & $84.32 \pm 2.94$ & $77.66 \pm 2.32$ \\
\hline $\mathrm{Fe}\left(\mathrm{mgL}^{-1}\right)$ & $0.07 \pm 0.002$ & $0.07 \pm 0.002$ & $0.08 \pm 0.002$ & $0.08 \pm 00.3^{*}$ & $0.07 \pm 00.2$ \\
\hline
\end{tabular}

Table 2:-Ground water characteristics of Moradabad city during post rainy season 2016

\begin{tabular}{|l|l|l|l|l|l|}
\hline Parameters & Civil lines & Bangla Gawn & PeetalNagri & Harthala & Krula \\
\hline pH & $7.14 \pm 0.12$ & $7.39 \pm 0.10$ & $7.25 \pm 0.11$ & $7.22 \pm 0.10$ & $7.56 \pm 0.21^{*}$ \\
\hline DO & $12.5 \pm 0.8$ & $23.5 \pm .1 .0^{*}$ & $18.2 \pm 0.9$ & $19.7 \pm .0 .9$ & $20.5 \pm 1.2$ \\
\hline Hardness $\left(\mathbf{m g L}^{-\mathbf{1}}\right)$ & $255 \pm 10.1$ & $206 \pm 8.01$ & $272 \pm 11.0$ & $355 \pm 12.4^{*}$ & $230 \pm 10.8$ \\
\hline Calcium $\left(\mathbf{m g L}^{-1}\right)$ & $55.01 \pm 2.5$ & $72.05 \pm 4.2$ & $72.08 \pm 5.0$ & $84.00 \pm 4.5^{*}$ & $64.10 \pm 3.3$ \\
\hline TSS $\left(\mathbf{m g L}^{-1}\right)$ & $60 \pm 2.3$ & $75 \pm 2.9$ & $80 \pm 3.0^{*}$ & $70 \pm 3.8$ & $85 \pm 4.01$ \\
\hline TDS $\left(\mathbf{m g L}^{-1}\right)$ & $177.9 \pm 9.4$ & $89.2 \pm 2.9$ & $115.3 \pm 4.2^{*}$ & $160.2 \pm 7.4$ & $151.8 \pm 5.8$ \\
\hline EC & $71.40 \pm 3.21^{*}$ & $82.1 \pm 3.89$ & $75.0 \pm 4.31$ & $83.3 \pm 5.01$ & $81.2 \pm 4.9$ \\
\hline Chloride $\left(\mathbf{m g L}^{-1}\right)$ & $53.71 \pm 2.4^{*}$ & $71.11 \pm 3.7$ & $83.01 \pm 4.01$ & $82.23 \pm 5.0$ & $76.00 \pm 5.2$ \\
\hline Fe & $0.06 \pm .002$ & $0.05 \pm 0.001^{*}$ & $0.07 \pm 0.002$ & $0.08 \pm .0 .002$ & $0.07 \pm 0.002$ \\
\hline
\end{tabular}

Values are mean of 6 replicates \pm standard deviation, significance at $\mathrm{p} \leq 0.05$.

* Monsoonal significant values during 2016.

Calcium: The calcium concentration ranged from $84.53-55.9 \mathrm{mgL}^{-1}$ in pre rainy season and the marginal value was $28.63 \mathrm{mgL}^{-1}$ whereas in post rainy season concentration was noted from $82-53.71 \mathrm{mgL}^{-1}$ and the average was 68.88 $\mathrm{mgL}^{-1}$ of all the studied sites. In post rainy atmospheric temperature decrease due to this evaporation rate of water falls in rainy season and its reach to the lower layer of the surface 
Chloride (Cl): The highest level of chloride is estimated at the site P. Nagari $86.14 \mathrm{mgL}^{1}$ followed by $84.33 \mathrm{mgL}^{-1}$ Harthal and the lowest level is estimated at civil line $56.73 \mathrm{mgL}^{-1}$ and in the post rainy season $\mathrm{Cl}^{-}$is found highest at the P. Nagari $83.01 \mathrm{mgL}^{-1}$ and the lowest at $53.71 \mathrm{mgL}^{-1}$ like same pattern of post rainy season Chloride was found much below as recommended by the WHO (1984) i.e. $500 \mathrm{mgL}^{-1}$. The level of chloride is noted more in pre rainy season.

Total Suspended Solids (TSS): The TSS is one of the most important water quality parameter that helps in determining the suitability of water used for different purpose the highest level of TSS was observed at the Kurla 87 $\mathrm{mgL}^{-1}$ and the lowest at the civil line $62 \mathrm{mgL}^{-1}$ whereas in post rainy season similar pattern was revised the highest level of TSS was observed at the Kurla $85.45 \mathrm{mgL}^{-1}$ and the lowest at the civil line $53.71 \mathrm{mgL}^{-1}$ and average of TSS was $74.33 \mathrm{mgL}^{-1}$. The increase in the quantity of TSS during summer season was also observed by Gupta et al., (2011).

Electrical Conductivity (EC): It influenced by the presence of ions in the form of dissolved solids and the ion level raise due to rise in pollution load. Electrical conductivity varies $88.2-73.5 \mu \mathrm{S} \mathrm{cm}^{-1}$ in pre rainy season however in post rainy season it was varies from 83.3-71.4 $\mu \mathrm{S} \mathrm{cm}^{-1}$. The highest level was observed at the site Harthal in both pre and post rainy.

Hardness: The permissible level of total hardness is $300-600 \mathrm{mgL}^{-1}$ (WHO, 1984). From table 1 and 2 highest level was found at Harthal in both the season 355 and $349 \mathrm{mgL}^{1}$ and the lowest level was found at B. Gawn site i.e. 202 and $206 \mathrm{mgL}^{-1}$ respectively while the average hardness in pre rainy season was 266.57 for post rainy season and $266.71 \mathrm{mgL}^{-1}$. Hardness in water is due to impact of the bicarbonates, sulphates and chlorides of salts (Jain and Agarwal, 2012), in the post rainy season respectively in both the season and at all the sites hardness was observed below the prescribed level.

Total Dissolve Solid (TDS): TDS shows the common nature of salinity of water. High amount of TDS causes a thin layer of salt in cooking vessel (Gupta et al., 2009). The range of total dissolve solid was observed between 180 to $92.2 \mathrm{mgL}^{-1}$ in pre rainy season, the highest range was found at the site Civil line and the lowest was noted at the B. Gawn while the average of the pre rainy season within the city from the selected sites was found $140.32 \mathrm{mgL}^{-1}$. In the post rainy season it was observed in the range of $177.9-89.92 \mathrm{mgL}^{-1}$ whereas it was also noted that at all the sites there was slightly decreasing in the TDS concentration during the post rainy season.

Iron (Fe): The high intake of $\mathrm{Fe}$ in human cause miss regulation of metabolism in the Center Nervous System (CNS) it can cause several neuro-generative disorders (Chandra et al., 2014). The range of Fe was noted 0.07-0.08 $\mathrm{mgL}^{-1}$ in pre rainy season and the highest level was observed at the site P. Nagari and Harthal. In post rainy season it was observed $0.05-0.08 \mathrm{mgL}^{-1}$. The remarkable decrease was noted at the site B. Gawn while on the other hand at site P. Nagari same amount was noted as in pre rainy season.

\section{Conclusion:-}

After the analysis of some water quality parameter of ground at Moradabad city from different selected sites, it is concluded that water is suitable for drinking purpose in both the pre rainy and post rainy season, the tested samples revealed that the ion like $\mathrm{Ca}^{++}, \mathrm{Cl}^{-}, \mathrm{Fe}$ are within the permissible limit and level of oxygen also specify that the microbial activity of the tested sample is also appropriate for the drinking purpose. The TSS and TDS level observed within the permissible limit as given by IS (1991) and WHO (1984)

\section{Reference:-}

1. APHA Standard Methods for the Examination of water and waste water (1995). 19 $9^{\text {th }}$ edition, Washington DC.

2. Chandra S., Rawat S. K., Garg S. K., Singh R. P. (2014): Seasonal variation of heavy metals (Fe and $\mathrm{Cu})$ in river Gomti of Lucknow city and comparative study of their phytoaccumulation by two natativemacrophytesTrapaNatansandMimulusGlabratus.International Journal of Ecosystems and Ecology Sciences, 4 (3),309-314

3. Chandra, S., Rawat S. K., Garg S. K., Singh R. P. (2012): Nitrate, Nitrite, Ammonium and Phosphate in various drinking and surface waters sources of Uttar Pradesh and Madhya Pradesh, India. International Journal of Plant, Animal and Environmental Science, 2 (3), 237-240 
4. Gupta A. K., Mishra K., Kumar P., Singh C. and Srivastava S., (2011):Impact of religious activities on the water characteristics of prominent ponds at Varanasi (U.P.), India. Plant Archives, 11 (1), 297-300

5. ISI., (1993): Specification for drinking water. 10500.ISI, New Delhi.

6. Jain S. and Agarwal M, (2012): Study on physico-chemical characteristics of ground water of various villages around Raisar, Journal of Chemical, Biological and Physical Sciences, 2(3), 1551-1555

7. Kumar N. (2010): Evaluation of Groundwater Quality in Shallow and Deep Aquifers: A Case Study, Report and Opinion, 2 (9), 75-87

8. Maiti S.K., (2001): Handbook of methods in environmental studies: water and waste water analysis, (1). ABD, publishers, Jaipur. (India)

9. Rizivi N., Gangwar R. K.., Chandra S., Singh J. and Singh A. P., (2013): Assessment of diverse resources of ground water quality in Bareilly district (U.P.), Journal of Chemical and Pharmaceutical Research, 5(8),54-58

10. Tewari A., Dubey A. and Trivedi A., (2010): A study on physico-chemical characteristics of Ground water quality, Journal of Chemical and Pharmaceutical Research, 2(2), 510-518.

11. WHO. (1984): Guidelines for drinking water quality, Recommendation, Geneva. 